Вито Флакер

Факултет за социјална работа

Универзитет во Љубљана, Словенија

\title{
ИНСТИТУЦИИТЕ КАКО СМРТОНОСНО ОРУЖЈЕ: СЛУЧАЈОТ НА СЛОВЕНИЈА ВО ПРВИОТ БРАН НА ЕПИДЕМИЈАТА КОВИД-19
}

\section{Апстракт}

Епидемијата Ковид-19 најмногу ги погоди старите луѓе, не оние кои живеат дома - туку оние во домови за стари лица. Во Словенија, дури четири петтини од починатите во епидемијата престојувале во овие институции. Анализата покажува дека суштинскиот момент на инфекција е институционалноста, а не возраста, дека во оваа смисла е скоро институционална епидемија. Шминкањето на вкупните институции претставува значително поголем ризик од пренесување на инфекција - како резултат на зголемената човечка концентрација и зголемената зачестеност на контакти, но и поради институционалната структура и етиката, кои ги објективизираат жителите и ги лишуваат од моќта на дејствување. Починатите жители може да се гледаат како (пасивни) жртви не само на вирусот, туку и на институционалната природа на организацијата за згрижување (која што преовладува во Словенија). Ова беше занемарено во досегашната дебата, воведените мерки не дозволуваа пренесување на грижата во заедницата, што ќе им обезбеди на жителите ниво на безбедност споредливо со населението во целина, таквите услуги овозможуваат поголем степен на самоизолација и контрола на контактите. Починатите жители се жртви на доцнење во деинституционализацијата и доцнење на воведувањето семоќна, долгорочна грижа во заедницата. Ова се итни задачи за иднината, ако сакаме да обезбедиме барем безбедност за старите лица, а со тоа и живот вреден за живеење.

Клучни зборови: корона вирус, домови за стари лица, целосна институција, деинституционализација, долгорочна нега

\section{Вовед}

Знаевме дека вирусот е опасен за старите и многу болните лица, меѓутоа, наскоро стана очигледно дека проблемот не е само „староста“, туку и институциите во кои се наоѓаат старите лица. Колку и да е очигледен, проблемот со концентрацијата на (старите) луѓе на едно место, дискусијата за старите луѓе и епидемиите во домовите за стари лица 
не успеаја да го споменат фактот дека домовите за стари лица во основа се целосни институции. Со овој пропуст, дебатата се оддалечи од хроничниот проблем на високата стапка на институционализација во Словенија (повеќе од 20.000 жители во 2 милиони жители) и избегна дискусија за потребата од воведување на долгорочна нега, како начин за замена институционалните капацитети и со тоа - обезбедување побезбедна нега.

Некои сметаат дека домовите за стари лица се места каде што обично се наоѓаат стари лица и го земаат здраво за готово фактот дека епидемиите се појавуваат на местата каде што живеат стари лица. Други пак, со право, се пожалија на недостаток на персонал во овие објекти. Се појави дилема, дали заразените стари лица треба да останат во домови за стари лица или треба да бидат префрлени во болници - бидејќи во домовите за стари лица нема персонал обучен за работа со инфекцијата. Беше покрената легитимна загриженост и критика за приватизацијата на институционалната грижа (иако, како што ќе видиме во Словенија, ова не беше прашање поврзано со епидемии). Дискусијата се фокусираше на прашањето за домовите за стари лица, но не навлезе во доблеста на ова прашање - концентрацијата на луѓето и постоењето на целосни институции. (Можеби перцепцијата беше сосема спротивна - дека имаме среќа да ги имаме - за време на епидемија.)
Контроверзноста за домовите за стари лица избувна само во времето кога епидемијата се смируваше (се совпадна со времето на овој преглед на податоците), по интервјуто со поранешниот министер за здравство, Душан Кебер во Младина на 16-ти мај (Јагер , 2020б). Интервјуто не само што го привлече вниманието кон големиот број смртни случаи во домовите за стари лица, туку и го осуди феноменот на стареење за време на епидемијата (лишување од соодветно лекување со неуспехот да се пренесат жителите во болниците), укажувајќи на фактот дека домовите за стари лица не се опремени за справување со болеста. Сепак, оваа критика сѐ уште тивко ја прифаќа аксиомата за неопходноста на ваквите установи и не го проблематизира нивното постоење и највисока стапка на институционализација во Словенија, ниту недостатокот на релевантни услуги во заедницата и грижата во заедницата, што, особено за време на епидемијата, може поефикасно и побезбедно, како и похумано, да одговори на маките на луѓето.

Оттука, ќе ја разгледаме најнапредната состојба и ќе се обидеме да ја разбереме динамиката на настаните, пред се, преку аспектот на институционализацијата како фактор на ризик. Засега, ова можеме да го направиме првенствено со преглед на релевантни податоци ${ }^{1}$ за раширената инфекција, идентификување на односите помеѓу

Сите податоци, освен ако не е поинаку наведено, се податоци од тракерот COVID-19 
возраста, институциите, (потврдените) инфекции и жртвите на инфекции. И тогаш ќе се обидеме да ги објасниме истите со теоријата на целосните институции и со анегдотски извештаи од областа.

\section{Вирусот го пренесува секој - старите лица умираат}

Секојдневните податоци за потврдени инфекции (ПИ) покажуваат дека инфекцијата се шири доста рамномерно низ возрасните групи, додека стапката на смртност не е распространета. Всушност, во тоа време, смртноста беше забележана во Словенија скоро

Https://covid-19.sledilnik.org/stats од 17-ти мај 2020 година и важеа за 16-ти мај. исклучиво во постари возрасни групи 100 од 104 починати лица биле постари од 65 години, а 84 лица биле над 75 години. Од друга страна, учеството на сите потврдени заразени лица во возрасната група над 65 години е 31,33\%, и 22,46\% за групата над 75 години.

На прв поглед на стапката на (потврдени) инфекции може да се претпостави дека постариот сегмент од населението повеќе страдал. Меѓутоа, кога ќе погледнеме детално, гледаме дека процентот во однос на населението во оваа група со мали отстапувања е релативно редовен за сите групи под 75 години, значително понизок за децата и значително повисок за најстарите (два до три пати повеќе)

Поголемиот број потврдени инфекции кај најстарите групи може да

Табела 1: Стапка на потврдени инфекции и смртност според возраста

\begin{tabular}{|c|c|c|c|c|c|c|c|c|}
\hline \multirow{3}{*}{$\begin{array}{l}\text { Возраст } \\
\text { Над } 85\end{array}$} & \multirow{3}{*}{$\begin{array}{c}\text { ПИ М } \\
36\end{array}$} & \multirow{3}{*}{$\begin{array}{c}\text { Ж } \\
134\end{array}$} & \multirow{3}{*}{$\begin{array}{c}\Sigma \\
170\end{array}$} & \multirow{2}{*}{\multicolumn{2}{|c|}{ \% од населението }} & \multicolumn{3}{|c|}{ Починати } \\
\hline & & & & & & \multirow{2}{*}{$\frac{\mathrm{M}}{14}$} & \multirow{2}{*}{$\frac{Ж}{44}$} & \multirow{2}{*}{$\frac{\Sigma}{58}$} \\
\hline & & & & 0,264 & 0,365 & & & \\
\hline $75-84$ & 72 & 87 & 159 & 0,132 & 0,106 & 15 & 11 & 26 \\
\hline $65-74$ & 72 & 60 & 130 & 0,071 & 0,053 & 10 & 5 & 15 \\
\hline $55-64$ & 117 & 102 & 217 & 0,079 & 0,069 & 2 & 0 & \\
\hline $45-54$ & 108 & 135 & 243 & 0,070 & 0,092 & 1 & 1 & \\
\hline $35-44$ & 90 & 112 & 202 & 0,055 & 0,076 & & & \\
\hline $25-34$ & 91 & 113 & 204 & 0,068 & 0,092 & & & \\
\hline $15-24$ & 42 & 60 & 102 & 0,042 & 0,064 & & & \\
\hline $5-14$ & 15 & 12 & 27 & 0,014 & 0,012 & & & \\
\hline $0-4$ & 4 & 4 & 8 & 0,008 & 0,008 & & & \\
\hline Вкупно над 65 & 180 & 281 & 459 & & & 39 & 60 & 99 \\
\hline Вкупно над 75 & 108 & 221 & 329 & & & 29 & 55 & 84 \\
\hline
\end{tabular}

Извор: COVID-19 tracker Https://covid-19.sledilnik.org/stats 


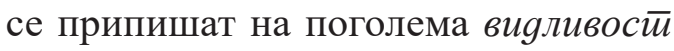
(поочигледни симптоми, подраматична манифестација на инфекција) и поголемо набљуgување (интензивно следење и набљудување, повеќе тестови). Две дополнителни хипотетички објаснувања може да се претпостават. Едно од нив е дека старите луѓе се повеќе изложени (според нивната социјална положба) или се подложни на инфекција, т.е. дека може да постои физиолошки механизам за полесно заразување со инфекцијата (тешко за верување) $)^{2}$.

Првите две хипотези упатуваат на изобличување на примерокот, на нужно пристрасен поглед, дека има скриени не видливи и не набљудувани - случаи и дека инфекцијата е всушност порамномерно распоредена во популацијата. Другите две толкувања, сепак, претпоставуваат дека вистинското ширење на инфекцијата е значително различно во старите возрасни групи - главно поради зголемената изложеност.

Од друга страна, скоро ексклузивната смртност кај старите лица може да се објасни лесно физиолошки, со текот на болеста. Поголемиот број смртни случаи кај постарите возрасни групи може да се припише на помала

\footnotetext{
2 Тука се повикуваме на механизмите на заразување со инфекцијата, а не со болеста. Имунитетот ја крие инфекцијата, ја прикрива нејзината видливост и не е проблем за пренесување на една личност. Прашањето на преносивањето би било на пр. состојбата на слуз поврзана со возраста. За лаиците таквата хипотеза е од примарна теоретска природа и скоро неверојатна, па дури и да е точна, тоа би објаснило само маргина на настани.
}

отпорност (повеќе хронични болести, на пример, срцева слабост, дијабетес мелитус, висок крвен притисок итн.). Сепак, поголемата зачестеност на фатални исходи може да се припише на поголемата изложеност.

Поголемата изложеност на старите луѓе не се должи на нивната поголема подвижност или повеќебројни контакти со повеќе можности за инфекција. Сосема спротивно, старите лица во просек имаат помалку контакти и се помалку подвижни. Сепак, ова важи за старите лица кои живеат дома (овие можат да бидат дури и помалку изложени за разлика од општата популација). Меѓутоа, оние што се во институциите, скоро во просек имаат повеќе контакти од луѓето кои, за да се одбранат од епидемијата, прибегнаа кон самоизолација. Изложеноста на староста е во концентрација на луѓе во институциите.

\section{Институции - фокусни точки на инфекции}

Односот помеѓу институциите и стапката на заразеност е видлив и во статистичките податоци. До 16-ти мај $^{3}$, имало 458 потврдени инфекции во домовите за стари лица, $31,26 \%$ од сите потврдени заразени во земјата. Од нив, 137 биле вработени и 321 жител $(21,91 \%$ или добра петтина од сите потврдени заразени во земјата - што е дваесет пати повеќе од учеството на

\footnotetext{
3 Ова беше приближно исто така времето кога стивна првиот бран на инфекција.
} 
жителите на институциите во населението). Ако додадеме 166 потврдени заразени во здравствениот сектор (персонал, а не пациенти ${ }^{4}$ ), имаше 624 или $42,59 \%$, скоро половина, од сите потврдени заразени во Словенија, во двата типа институции.

Врз основа на овие бројки, можеме да потврдиме дека феноменот на корона вирусот е тесно поврзан со институциите, бидејќи добар дел од инфекциите може да се објаснат со заразени лица што живеат или работат во институции. Како и во случајот на разликите во возраста, еден дел од овој „статистички“ феномен може да се припише на собирање на податоци - т.е. видливост и набљудување - поизразени симптоми и поголемо внимание и тестирање отколку надвор од институциите.

Податоците за смртноста се меѓу збирките на податоци кои се најмалку контаминирани со „искривеност на земање мостри“ - видливост и набљудување. Неуспехот да се припише фатален исход од оваа болест, може да се појави во статистиката во раните фази на епидемијата, но кога вниманието е насочено кон болеста, можеме да претпоставиме дека интервалот на таквата грешка е значително потесен. Податоците за починати во домовите за стари лица, за жал, не беа достапни до крајот на првиот бран на епидемијата. ${ }^{5}$

\footnotetext{
4 Податоците за тоа колку пациенти се заразиле во болниците не се достапни.

5 Овие беа јавно објавени дури по 15-ти мај, по интервјуто со д-р Кебер. Случајно, ова беше времето кога започна работата на словенечката
}

\section{Домови за стари лица - скоро ексклузивна територија на корона}

Инфекцијата е регистрирана во шест домови за стари лица во Словенија, т.е. 5\% од сите такви установи (125). ${ }^{6}$ Бројот може да изгледа мал, тоа е само „мал број“" на институции и, сепак, истиот е значително повисок од нивото на инфекција кај целата популација, за кое се очекуваше да биде $2 \%$ во тоа време.

Речиси сите потврдени институционални инфекции (441 - 96\%) се регистрирани во овие шест институции. Сeпак, степенот на контаминација во овие шест домови значително се разликува. Во два дома (Љутомер, Шмарје) повеќе од половина, скоро две третини од жителите и скоро половина од персоналот се заразиле со инфекција. Во други два дома, стапката на инфекција сѐ уште беше значителна - инфекцијата беше потврдена со скоро третина од жителите и скоро со петтина од вработените во Метлика, додека во Хорјул беа заразени нешто повеќе од една петтина од жи-

верзија на овој труд. Бидејќи немаше податоци за бројот на починати на располагање, проценката требаше да се реконструира врз основа на податоците за потврдени инфекции во домови за стари лица (кои беа достапни) и податоците за потврдени инфекции по возрасни групи и општини. Линијата на текст внимателно ја следи оваа линија на размислување. (Проценката беше потврдена еден или два дена подоцна).

6 Очигледно, имаше уште неколку домови (три до четири) освен оние откриени во официјалната статистика (Ковач, 2020). Но, со оглед на малите бројки, бројките што ги цитираме доволно ја гарантираат нашата аргументација. 
телите и една десетина од персоналот. Додека во другите две институции (Бокалци и Накло) епидемијата има само маргинален изглед.

Заразените домови беа доста разновидни по големина, меѓу нив имаше многу мал (прв квинтил, Накло), мал (втор квинтил - Хорјул), поголем (гранична вредност на трет квинтил Љутомер), голем (четврт квинтил - Метлика) и два беа меѓу најголемите (петти квинтил Шмарје (гранична вредност) и
Изненадувачка карактеристика на овие податоци е дека бројот на потврдени инфекции кај жителите е доследно поголем отколку кај вработените (освен за Накло, каде што бројот е мал за двете категории). Би можело да се очекуваат повисоки бројки кај вработените бидејќи тие ја донесуваат инфекцијата и заради нивната подвижност се повеќе изложени на контакти итн.

Вкупниот број на жители со потврдена инфекција беше 321, додека кај

Табела 2: Број на потврдени инфекции во дом за стари лица, во однос на големината на установата

\begin{tabular}{|c|c|c|c|c|c|c|c|c|c|}
\hline $\begin{array}{l}\text { Инсти- } \\
\text { туција }\end{array}$ & $\Sigma$ & $\begin{array}{r}\text { ПИ } \\
\text { жители }\end{array}$ & $\begin{array}{r}\text { ПИ } \\
\text { персонал }\end{array}$ & $\begin{array}{r}\text { ПИ } \\
\text { жители } \\
(\%)\end{array}$ & $\begin{array}{r}\text { ПИ } \\
\text { персонал } \\
(\%)\end{array}$ & $\begin{array}{r}\text { Бр. на } \\
\text { жители }\end{array}$ & $\begin{array}{r}\text { Бр. на } \\
\text { персонал }\end{array}$ & $\begin{array}{l}\text { Жители/ } \\
\text { персонал }\end{array}$ & Ранг \\
\hline Шмарје & 181 & 124 & 57 & 57,94 & 46,72 & 214 & 122 & 1,754098 & 100. \\
\hline Љутомер & 139 & 99 & 40 & 63,87 & 45,45 & 155 & 88 & 1,761364 & 71,5 . \\
\hline Метлика & 71 & 53 & 18 & 30,81 & 18,37 & 172 & 98 & 1,755102 & 78,5 . \\
\hline Хорјул & 26 & 21 & 5 & 21,88 & 9,09 & 96 & 55 & 1,745455 & 28. \\
\hline Бокалци & 20 & 17 & 3 & 4,50 & 1,40 & 378 & 215 & 1,758140 & 123. \\
\hline Накло & 4 & 2 & 2 & 4,35 & 7,69 & 46 & 26 & 1,769231 & 9. \\
\hline $\begin{array}{l}\text { Вкупно } \\
\text { (одбрани } \\
\text { домови) }\end{array}$ & 441 & 316 & 125 & 29,78 & 20,70 & 1061 & 604 & & \\
\hline $\begin{array}{l}\text { Други } \\
\text { домови со } \\
\text { ПИ }\end{array}$ & 17 & 5 & 12 & & & & & & \\
\hline Вкупно & 458 & 321 & 137 & & & 20431 & 11646 & & \\
\hline
\end{tabular}

Извор: COVID-19 tracker Https://covid-19.sledilnik.org/stats

Бокалци). Сите, освен една, беа јавни институции и сите имаат многу слична стапка на вработени и жители. Нивната заедничка карактеристика може да биде тоа што тие се наоѓаат на периферијата, сите освен Бокалци (Љубјана), се наоѓаaт во мали гратчиња. вкупната популација бројот на потврдени инфекции за возрасната група над 65 години беше 459. Потврдените инфекции во домовите за згрижување се сметаат за 70\% (69,93\%) од потврдени заразени лица во возрасната група над 65 години. Сепак, жителите на домови- 
те за стари лица во просек се значително постари, а статистичките податоци за потврдени инфекции покажуваат дека во возрасната група над 75 години имало само осум (8) случаи повеќе од бројот на лица потврдени заразени во институциите, што значи дека жителите на домовите за стари лица сочинуваат 96,5\% од потврдените инфекции во возрасната група над 75 години.

Изложеноста на старите лица на инфекцијата може да се смета пред се, или скоро исклучиво на живеалиштето во домовите за стари лица.

Статистиката за смртност во домови за згрижување (првично недостапна) покажува дека најмалку 86 жители на домови за стари лица починале, што е повеќе од $80 \%(81,13 \%)$ од вкупниот број на луѓе кои починале од оваа болест. Според тоа, институционалната позадина објаснува повеќе од четири петтини од фаталните исходи на оваа болест; во возрасната група над 75 години скоро сите (86).

Затоа, институционалната позадина е апсолутна корелација, ако не и причина за смртноста кај старите луѓе - и доминантна за целото население.

\section{Географската распределба на смртноста е институционална}

Следниот извор на широко достапни податоци беше епидемиолошката состојба во општините. Кога ја набљудуваме картата за стапки на инфекции и морталитет, на прв поглед е јасно дека општините, во кои се наоѓаат соодветните домови, се истакнуваат.

\section{Слика 1: Број на потврдени инфекции од страна на општините во Словенија}

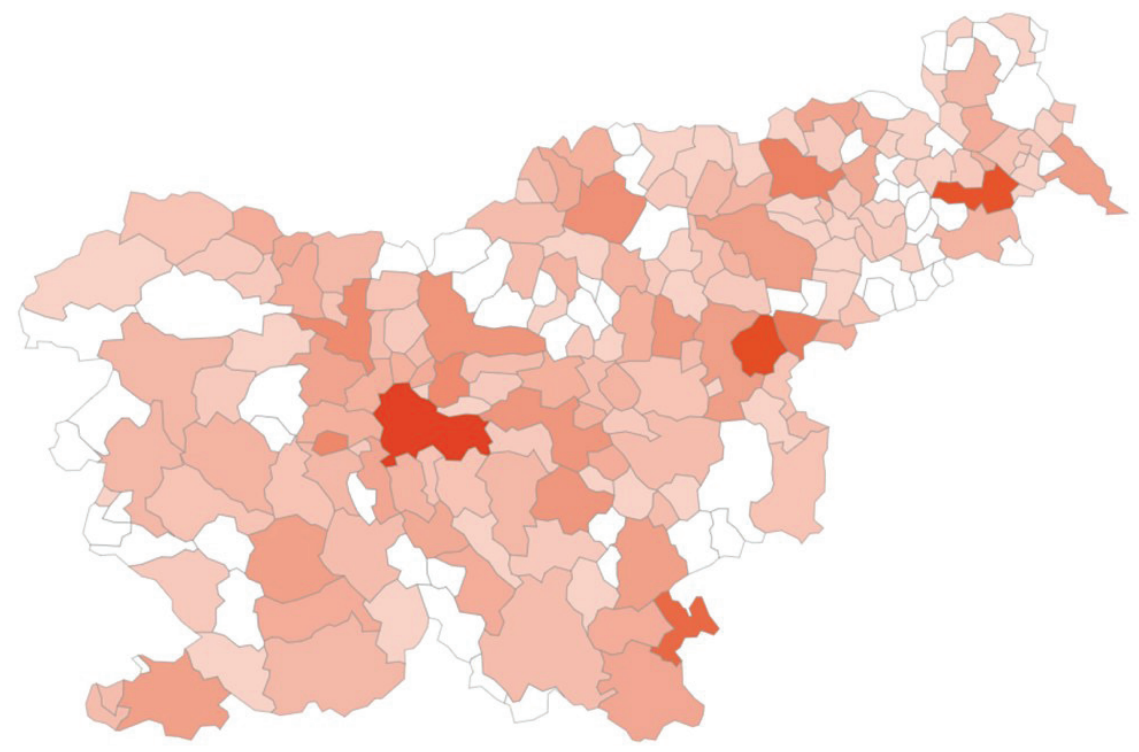

Извор: COVID-19 tracker Https://covid-19.sledilnik.org/stats 


\section{Слика 2: Стапка на смртност во однос на бројот на жители на општина, во Словенија}

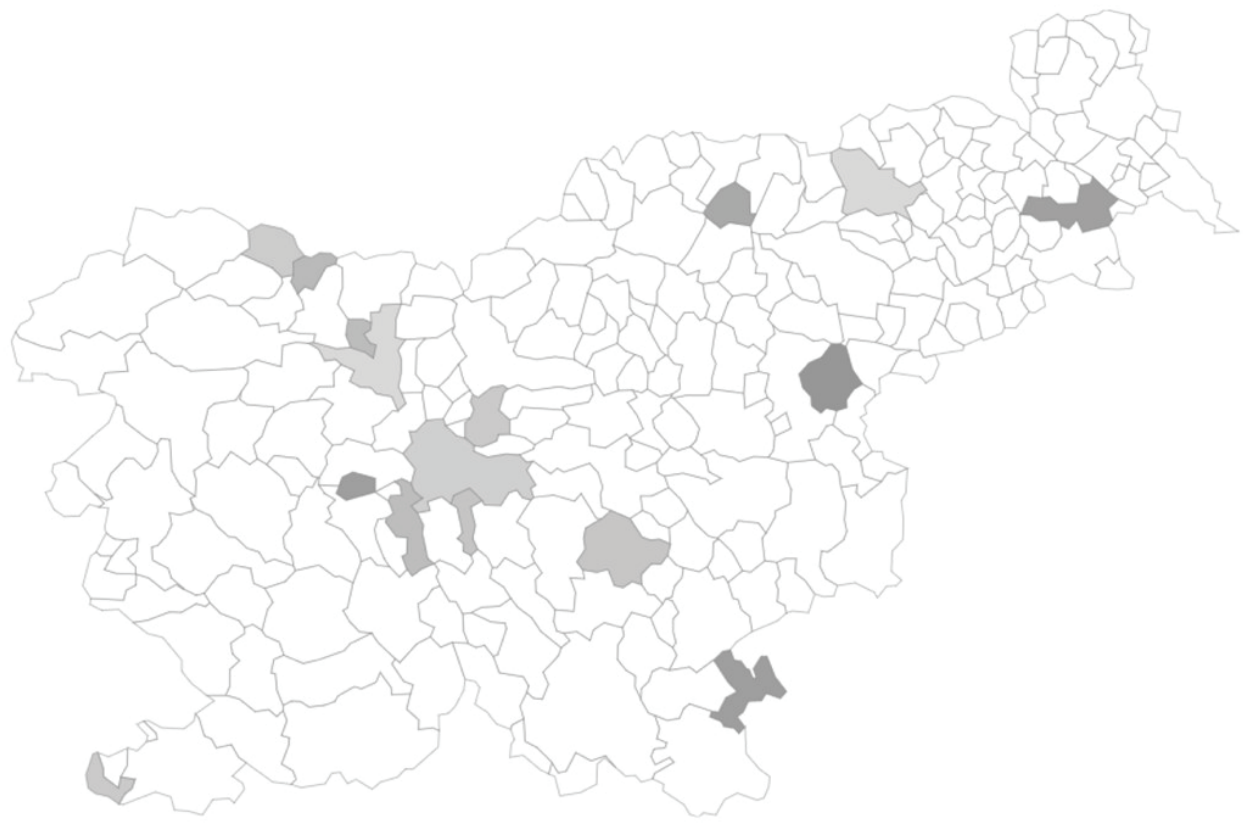

Извор: COVID-19 tracker Https://covid-19.sledilnik.org/stats

Таму, нивото на потврдени инфекции е поголемо; на картата, што претставува географска распределба на смртност, со неколку исклучоци (види табела во прилог), насекаде (освен Љубљана) е празно подрачје.

Ова е потврдено со нумеричката споредба. Бројот на потврдени инфекции е скоро идентичен (освен Љубљана) со бројот на потврдени инфекции во домовите за згрижување. ${ }^{7}$ Идентитетот

7 Во некои општини (Накло, Шмарје, Љутомер) бројот на потврдени инфекции е дури и помал отколку во домовите за згрижување. Можеби некои жители имаат постојана адреса во друга општина или инфекцијата е регистрирана на друго место (на пример, општина на болницата). Метлика и Хорјул, исто така, имаат само уште два случаи во општината за на броевите е уште поочигледен во случајот со статистиката за смртност. Во општините каде се наоѓаат контаминирани домови за нега, имало 90 фатални случаи или $86,54 \%$ од сите фатални исходи во земјата. Ако ја исклучиме општината Љубљана, имаше 79 такви случаи, сѐ уште повеќе од три четврти-

разлика од тоа што е забележано во домот за стари лица. Според здравиот разум, би можеле да го очекуваме спротивното - дека, како и во Љубљана, ќе има поголема стапка на ПИ во животната средина отколку во самиот дом за згрижување. Ова укажува, или дека во овие средини тестовите биле извршени скоро само во стари домови, или дека вирусот едвај се ширел во околината. Сепак, исто така во Љубљана, случаите откриени во домот за згрижување во Бокалци претставуваат скоро десетина $(7,87 \%)$ од сите откриени случаи. 
Табела 3: Број на потврдени инфекции по општини

\begin{tabular}{|l|r|r|r|r|r|}
\hline општина & ПИ & Починати & $\begin{array}{r}\text { ПИ \% } \\
\text { жители }\end{array}$ & $\begin{array}{r}\text { починати \% } \\
\text { население }\end{array}$ & $\begin{array}{r}\text { Смртност } \\
\text { на ПИ }\end{array}$ \\
\hline Шмарје & & & & & \\
\hline Љутомер & 174 & 37 & 1,693 & 0,360 & 21,3 \\
\hline Метлика & 135 & 19 & 1,198 & 0,169 & 14,1 \\
\hline Хорјул & 73 & 16 & 0,869 & 0,191 & 21,9 \\
\hline Љубљана & 28 & 6 & 0,923 & 0,198 & 21,4 \\
\hline Накло & 254 & 11 & 0,086 & 0,004 & 4,3 \\
\hline Збир на општините & 3 & 1 & 0,056 & 0,019 & 33,3 \\
\hline без љубљана & $\mathbf{6 6 7}$ & $\mathbf{9 0}$ & & & 13,49 \\
\hline Тотаl & 413 & 79 & & & 19,13 \\
\hline Differenсе & 1465 & 103 & & & 7,03 \\
\hline
\end{tabular}

Извор: COVID-19 tracker Https://covid-19.sledilnik.org/stats

ни $(75,96)$ од сите смртни случаи. Ако додадеме неколку случаи од Љубљана (дом во Бокалци), би стигнале до бројка од 83 починати во домови за стари лица, што е 79,81\% од починатите во земјата.

Географската репрезентација на потврдените инфекции, особено на смртноста, се чини дека е еуфемизам, што ги претставува навистина домовите за згрижување отколку општините. Сепак, овој поглед илустрира дека станува збор за институционална епидемија или епидемија за која е потребен број на жртви, скоро исклучиво во институциите.

Прегледот на достапната статистика може да се заклучи со наведување дека

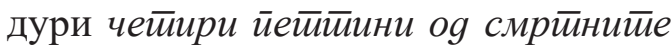
случаи биле йоврзани со домови за сйари лицуа. Може gа се йврgи дека сйанува збор за инфекичија или ейиgемија, која е йрейежно или барем во іолема мера инсииийуционална.

По ова откритие можеме да претпоставиме:

- Или, жителите на домовите за стари лица се помалку издржливи,

- Или дека старите домови се фактор на поширока и побрза контаминација.

Вистината е веројатно некаде помеѓу хипотезата за институционализмот како моментум на ширење инфекција и за староста како фактор на смртност. Динамиката на ширење на инфекцијата во неколку домови за згрижување укажува дека институционалниот момент бил, барем во набљудуваниот период, веројатно посемоќен фактор. 


\section{Институциите како (најмоќен) фактор на ризик - како карактеристиките на домовите за згрижување придонесуваат за ширење на инфекцијата}

Дека институциите се идеален агар медиум за култура - за болести и инфекции е јасно веќе подолго време. Дури и без податоци и истражувања, може да се види дека во големи концентрации на луѓе, има значително поголема шанса за контакт и пренесување на инфекција. Ние исто така знаеме болести, кои луѓето ги фаќаат само на места од ваков вид (легионела, CA-MRSA) или болести кои претежно живеат во институции (на пр., Ротавирус во домови за стари лица и градинки). Болеста корона не се појавува како една од нив, но она што го кажуваат бројките не е далеку од тоа. Веројатно станува збор за комбинација на две карактеристики на епидемија пренос во општото општество, кој се концентрира во институциите. Затоа, во случај на епидемија на нов корона вирус корона, институциите се јазол на пренесување, а исто така, со оглед на стапката на смртност, и неговата последната станица.

Таквите институции имаат, меѓу другото, две карактеристики. Првиот е сегрегација, второто конгрегација. Тие се релативно одделени од нивната околина, понекогаш дури и изолирани, истовремено има голем број луѓе од посебна категорија сместени во нив. ${ }^{8}$ Со други зборови, би можеле да кажеме дека е тешко за вирусот да влезе во институцијата, но кога е таму, има многу можности за негово размножување и пренесување. Во овој контекст, ваквите институции, во случај на КОВИД, особено домовите за стари лица, се како темпирани бомби, кои чекаат случајно испуштање.

\section{Пренесувачи и шепкачи наспроти пасивни жртви}

Иако домовите за грижа се релативно изолирани, тие се, за разлика од, на пример, изолирано планинско село, кое може да биде прилично самостојно, многу зависни од околината; дури и затворите со максимална безбедност не можат да спречат влез на најзабранети работи (дрога, оружје). Внесувањето на вирусот не е, се разбира, намерен чин, туку лапсус, немил настан, веројатност (и скоро сигурност, како што се покажа) бидејќ́ дури и во случај на забрана за посети, вработените и добавувачите на разни стоката влегуваат во домот. Рестриктивните мерки и строгите контроли можат да ја намалат веројатноста за влез, но не можат да го спречат целосни.

За опис и анализа на вкупните институции, видете го класичното дело на Гофман „Азилуми“ (1961), како и делото на авторот на оваа тема (на пример, Флекер, 1998, 2015). За третман на домови за стари лица како целосни институции, видете(Мали, 2008). 
Имајќи предвид дека домашните посети беа забранети многу брзо и на жителите не им беше дозволено да ги напуштаат просториите, увозот на вирусот во домовите за згрижување може да се припише на вработените, кои се повеќе мобилни и имаат повеќе контакти со околината. ${ }^{9}$ Со оглед на тоа што последниот влез на вирусот во набљудуваниот период е забележан на 1-ви април, можеме да претпоставиме дека прекинот на влегувањето на вирусот во домовите за згрижување е најверојатно резултат на построги мерки надвор (ограничување на движењето помеѓу општините, итн. .) отколку мерките во самите домови за згрижување.

Меѓутоа, ако тие беа во можност да ги ограничат контактите помеѓу жителите (на пр., да не седат заедно во сала, групни активности, меѓусебни посети, итн.), движењето на персоналот и нивниот контакт со неколку жители не може да биде целосно ограничено. Во оваа смисла, персоналот е склон пренесувач на вирусот. ${ }^{10}$ Жител, исто така, во случај на ограничувања, има

9 Превод од англиски јазик. Според статистичките записи, инфекцијата најпрво била откриена кај вработените во три домови за грижа и кај жителите во другите три домови. Сепак, ова не ни кажува за агентот на влезот, кој веројатно во сите случаи биле вработените, можеби некој друг, а најмалку жителите.

10 Гофман (1961) ги опишува механизмите на (недозволен) транспорт на стоки и пренесување на информации во целосните институции. Меѓу важните канали на оваа активност се вработените, кои имаат многу можности за движење помеѓу одделенијата, и помеѓу институцијата и надворешниот свет. контакт со двајца или тројца вработени барем, најверојатно повеќе (околу пет). Од друга страна, негувателка има контакт со жителите на целиот оддел каде што таа или тој служи.

Иако, би можеле да претпоставиме дека вработените се повеќе изложени, бројките сугерираат поинаку. Во пет домови $^{11}$ постои постојана разлика од 10 до 15 проценти помеѓу нивото на потврдена контаминација на вработените и жителите. Оваа разлика може да се објасни со фактот дека целиот персонал не е изложен на контакт со друг персонал (администрација, некои би работеле од дома); но исто така и од побројните и поинтензивни контакти на вработените со жителите во процесот на згрижување.

Сепак, разликата во изложеноста исто така може да се толкува со различен степен на претпазливост и внимание. Некои може да бидат повнимателни, да посветат поголемо внимание на хигиената, далечината итн., Додека други се помалку внимателни. Ова зависи делумно од атмосферата и ставовите на институцијата, нејзиниот менталитет и делумно од личниот став на секој вработен. Во двата случаи, покрај невниманието како одлика на личноста или колективна немарност, што може да биде и резултат на поставувањето на институцијата, односот со жителите е важна случајност.

11 Шестиот беше мал со многу малку потврдени инфекции. 
Објектификацијата на жителите е имено една од заедничките карактеристики на целосните институции. Институционалната грижа е организирана според принципите на индустриско, масовно производство. Таквиот став и врски се всушност бирократска спојка, но функционира и како одбранбен механизам од вознемиреност што може да биде предизвикана од приврзаност кон жител (Мензи, 1988), а исто така е резултат на фокусирање на физичка нега и вршење на „технички“ задачи, што е заедничка ориентација на институциите за згрижување. Сето ова честопати значи дека персоналот ги перцепира и ракува со жителите како предмети на нивната работа (грижа) и помалку како луѓе со свои желби, грижи, врски и лични истории.

Во услови на епидемија, зголемена изолација (затворање), помалку посети, итн. ваквиот став со некои вработени или во некои институции може да се интензивира. Особено, ова може да стане „агар“ за размножување на „егоистички“ став или невнимателен став кон епидемијата и пренесувањето на вирусот. Постојат две чисто човечки, етички заштитни мерки за претпазливост на безбедноста во врска со преносот. Можам да внимавам да не се заразам, но ако не се грижам за себе - затоа што сум млад или затоа што сум се откажал од судбината или затоа што социјалниот живот или економската добивка ми се поважни од здравјето - постои „безбедносен вентил“ за грижата за благосостојбата на друго лице. „Ке внимавам да не заразувам други луѓе, важни луѓе за мене“. - на пр. внук нема да се дружи со пријателите затоа што ја посетува својата баба или напротив, нема да ја посети својата баба затоа што се дружел со врсниците. ${ }^{12}$

Колку повеќе вработените ја дефинираат својата работа како работа со предмети отколку со луѓе, толку е поголема можноста вработените да не го гледаат другиот како личност; нема да им биде грижа дали носат маска во нивно присуство или дали ќе ги почитуваат упатствата или не. Позицијата и моќта на жителите, зависни од персоналот, е таква што на жителите им е тешко да ги истакнат грешките и недоследностите на вработените, па дури и да ги направат, не е многу веројатно дека вработените ќе ги слушаат. ${ }^{13}$

Достапните податоци покажуваат дека домовите за нега, во кои влегол вирусот, се разликуваат во степенот на ширење на контаминацијата. Во два дома достигна скоро две третини од жи-

12 Институционализацијата со ставање на лице под институционален авторитет и старателство ослободува токму од оваа, втора одговорност и солидарност.

13 Гофман (ibidem) го опишува подживотот на целосните институции. И жителите и персоналот на установата треба да учествуваат во разни неовластени, несакани или официјално непредвидени активности кои овозможуваат отстапување од пропишаните улоги. Одбегнувањето и затајувањето е начин на живот во ваквите институции. Затоа, не можеме да бидеме изненадени што некои работници нема да следат правила, упатства или други мерки. Тие ќе ја олеснат нивната работа, ќе ги осветлат своите рутини, ќе се изразат и ќе го поминат денот. 
телите, што е, случајно, вредноста, за која се претпоставува дека претставува , имунитет на стадо“, во следниве два дома, една третина или петтина од жителите биле заразени, а во два домови вредностите беа со едноцифрен процент. Затоа може да се каже дека во првиот случај вирусот се шири релативно неконтролирано, во два случаи тој беше запрен во одредена фаза и веднаш беше сопрен во последните два домови (види Табела 2 погоре). Ова можеше да биде резултат на збир на околности или може да биде ефект на соодветен одговор (дури и можеби ненамерно) - ова не го учиме од бројките. Сепак, ова треба да се испита, токму за подобри насоки во иднина (втор бран на епидемија).

Во институциите со две или повеќекреветни соби, можностите за пренесување се поголеми (како резултат на контактите меѓу цимерите, зголемената зачестеност на доаѓње на персоналот и премалото растојание помеѓу креветите). Самоизолацијата во домовите за нега е практично невозможна, дури и кога во некои домови жителите на еднокреветни спални беа затворени во своите соби. Во табелата подолу, гледаме дека домовите каде што се појавиле инфекции, со исклучок на Накло, се далеку под националниот просек во

Табела 4: Пропорции на еднокреветни и повеќекреветни соби во домови за социјална грижа

\begin{tabular}{|l|l|r|r|r|r|r|r|r|r|r|}
\hline вид & $\begin{array}{r}\text { Број на } \\
\text { места }\end{array}$ & $\begin{array}{r}\text { ррој на } \\
\text { соби }\end{array}$ & $\begin{array}{r}\text { Жит. } \\
\text { /соба }\end{array}$ & $\begin{array}{r}1 \text { кре- } \\
\text { вет }\end{array}$ & $\begin{array}{r}2 \text { кре- } \\
\text { вети }\end{array}$ & $\begin{array}{r}3 \text { кре- } \\
\text { вети }\end{array}$ & $\begin{array}{r}4 \text { кре- } \\
\text { вети }\end{array}$ & $\begin{array}{r}5 \text { кре- } \\
\text { вети }\end{array}$ & $\begin{array}{r}\text { Апарт- } \\
\text { ман }\end{array}$ \\
\hline $\begin{array}{l}\text { Шмарје во } \\
\text { Јелшах }\end{array}$ & Јавна & 214 & 118 & 1,81 & 36 & 68 & 14 & & & \\
\hline процент & & & & & $\mathbf{3 0 , 5 1}$ & $\mathbf{5 7 , 6 3}$ & $\mathbf{1 1 , 8 6}$ & & & \\
\hline Накло & Јавна & 46 & 38 & 1,21 & 30 & 8 & & & & \\
\hline процент & & & & & $\mathbf{7 8 , 9 5}$ & $\mathbf{2 1 , 0 5}$ & & & & \\
\hline Хорјул & Приватна & 155 & 92 & 1,68 & 32 & 57 & 3 & & & \\
\hline процент & & & & & $\mathbf{3 4 , 7 8}$ & $\mathbf{6 1 , 9 6}$ & $\mathbf{3 , 2 6}$ & & & \\
\hline Бокалци & Јавна & 378 & 192 & 1,97 & 56 & 86 & 50 & & & \\
\hline процент & & & & & $\mathbf{2 9 , 1 7}$ & $\mathbf{4 4 , 7 9}$ & $\mathbf{2 6 , 0 4}$ & & & \\
\hline Љутомер & Јавна & 172 & 103 & 1,67 & 36 & 61 & 6 & & & \\
\hline процент & & & & & $\mathbf{3 4 , 9 5}$ & $\mathbf{5 9 , 2 2}$ & $\mathbf{5 , 8 3}$ & & & \\
\hline Метлика & Јавна & 172 & 94 & 1,83 & 22 & 66 & 6 & & & \\
\hline процент & & & & & $\mathbf{2 3 , 4 0}$ & $\mathbf{7 0 , 2 1}$ & $\mathbf{6 , 3 8}$ & & & \\
\hline $\begin{array}{l}\text { Вкупно } \\
\text { Словенија }\end{array}$ & & 18.962 & 11.580 & 1,69 & 5.206 & 5.384 & 595 & 358 & 35 & 14 \\
\hline регсепt & & & & & $\mathbf{4 4 , 9 1}$ & $\mathbf{4 6 , 4 5}$ & $\mathbf{5 , 1 3}$ & $\mathbf{3 , 0 9}$ & $\mathbf{0 , 3 0}$ & $\mathbf{0 , 1 2}$ \\
\hline
\end{tabular}

Извор: SSVZS - kapacitete - domovi za starejše in posebni svz; accessible at: http://www.ssz-slo. si/wp-content/uploads/Register-kapacitet-1.1.2020.pdf 16.5. 2020 
однос на бројот на еднокреветни соби (националниот просек не е самиот поволен - во некои земји, како Австрија, стандардот е еднокреветна просторија подолго време), додека овие имаа повеќе повеќекреветни соби од словенечките домови за згрижување во просек.

Оваа одлика укажува на тоа дека контаминираните домови за нега не биле установи што инвестирале во приватноста на жителите и во персонализирање на услугите.

\section{Целосност на институцијата - најголем фактор на ризик}

Дискутирајќи за достапните податоци, успеавме да идентификуваме одредени фактори кои веројатно придонеле за ширење на епидемијата во домовите за стари лица. Видовме дека големината на институцијата, иако не е клучна, може да биде важна - контаминираните домови беа во просек од поголем вид. Видовме дека во повеќето случаи тоа беа рурални домови. ${ }^{14}$ Исто

14 Нема очигледно објаснување за оваа хипотеза. Можеби периферијата значи уште поголем степен на чувство на сегрегација, инаку карактеристично за целосните институции, „да бидат надвор од видното поле (на општото општество)“. Може да биде и периферно „размислување“", често типично за селата, имено дека „оваа (епидемија) се случува на друго место - во Кина, Италија, Љубљана, или можеби дури и во соседна општина, но не и кај нас. „Таквата тактика на,„ној“ е одлика и на целосните институции, во кои постои игнорирање, па дури и презир кон она што се случува надвор. Во исто време, исто така, постои страв од инциденти, кои, според воспоставената практика, по така, видовме дека контаминираните објекти имаат повеќе соби со повеќе кревети, што покрај поголема можност за пренесување на вируси, укажува на недостаток на ориентација кон персонализирање на одредбата. ${ }^{15}$

Сепак, најочигледната и најконтроверзната хипотеза (или објаснување) е дека домовите за згрижување се целосни институции - не само со големата концентрација на луѓе, туку и со карактеристична атмосфера, перцепција на луѓето како предмети, неврамнотежни односи меѓу персоналот и жителите и недостатокот на моќ на вторите. Ова би можело значително да го олесни ширењето на инфекциите. Дополнително, вработените се носители на инфекции, додека жителите се приматели и жртви на тоа (повисоки стапки на инфекција, потешки последици). Сепак, моравме

можност се постапуваат во целосни институции на начин да се сокријат, што е можно повеќе во затскриена установа отколку надвор. Во некои домови во Италија е забележано прикривање (за да сочуваат образ) на инфекцијата во стари домови.

15 Овие домови не се издвојуваат за иновации или воведување на персонализирани услуги и механизми за зајакнување на жителите (Мали и сор., 2018). Исто така, според статистичките податоци на Здружението на домови за социјална грижа, контаминираните домови имаат многу мала понуда над класичната институционална грижа. Дневната грижа се обезбедува само во три од шесте домови и тоа само за релативно мал број корисници (Шмарје 9, Љутомер 8 и Бокалци 6 дневни посетители). Домот за згрижување во Љутомер има седум заштитени станови, домашната помош е обезбедена од установи во Шмарје и Метлика, но само за еден корисник. 
да ја отфрлиме хипотезата што кружеше, што може да биде вистина во други земји, дека приватните домови се изложени на поголем ризик од ширење инфекции, дури и ако овој ризик постои во принцип, бидејќи приватните домови треба да водат поголема грижа за ,економијата“" на бизнисот. ${ }^{16}$

Големината, видот на институцијата, ориентацијата, атмосферата, бројот на еднокреветни соби, односите персонал-жител, како и силата на корисникот и стилот на управување, се фактори кои многу јасно влијаат на ширењето на вирусот низ установата, но имаат помало влијание врз нејзиниот влез. Ако ова се клучни прашања за ширење на инфекција, тие се повеќе или помалку случајни или индиректни за нејзино влегување (на пр. поголемите институции имаат повеќе неопходни контакти со околината и затоа поголема можност за влез на вирусот, повеќе или помалку личен и одговорен однос кон жителите исто така може да има значење во внимателноста при внесувањето на нештата во објектот и нивното лично

16 Во Словенија, приватните домови формално не се заради профит, но сепак го бараат истиот на разни страни. Во земјите каде што е дозволена грижа за профит, поттикот за заработка на сметка на жителите е поистакнат, бидејќ́ профитот е на прво место, а само потоа луѓето. Значи, дури и ако нашите податоци не ја потврдат таквата хипотеза, тие не смеат да бидат отфрлени како ирелевантни во иднина. На крајот на краиштата, за среќа, времето на првиот бран на епидемијата беше доволно кратко за да се покажат сите можни импликации врз функционирањето на институциите и ќе се демонстрираат на подолг период. однесување надвор од домот и будноста при сопствената контаминација). Со сите овие можни ефекти, сепак, можеме да заклучиме дека влегувањето на вирусот во домовите за нега е повеќе или помалку случаен настан, во кој се случи ова, тоа беше повеќе несреќен случај отколку некое лошо дело. Влегувањето на вирусот во институциите е неизбежно, уште повеќе во Словенија, која е на врвот според стапката на институционализација (број на жители на институции по популација) (Хубер и сор., 2009), а тоа се рефлектира и во меѓународната статистика за смртни случаи во домови за социјална грижа каде што бројот на смртни случаи во Словенија ја надминува за дури 20\%, највисоко рангираната земја. ${ }^{17}$

\section{Грижа во заедницата - обезбедувач на сигурност}

Најзначајниот и најчестиот фактор на фатални инфекции беа - заради концентрацијата на луѓето и нивната внатрешна структура и функционирање - институциите. Овој факт беше заобиколен бидејќи постоеше впечаток дека нема вистински алтернативи за институционалната грижа. Но, тие се,

\footnotetext{
17 Активист за старост Бисерка Меден (2020) на својата страница на Фејсбук обезбедува податоци за неколку европски земји објавени од ЛСЕ (лондонско школо за економија). Во споредба со нашите $80 \%$, смртноста поврзана со Ковид-19 кај институциите е: во Ирска 60\%, во Франција 51\%, во Шведска 45\%, Португалија $40 \%$, во Германија $36 \%$, во Данска $33 \%$ и Унгарија 19\%.
} 
и кардиналниот грев во последните децении извршен од креаторите на политики беше дека Словенија никогаш не започнала со деинституционализација и не успеала да воведе долгорочна грижа за замена на институционалната грижа на квалитетен начин.

Се разбира, проектот за долгорочна нега е, во голема мерка, напор за деинституционализација - тој треба да ја замени институционалната нега со интензивна нега каде што живеат луѓето, во заедницата. Сепак, во Словенија, долгорочната грижа неодамна, особено во дебатите за корона, стана синоним за институционална грижа: “Областа на долгорочна грижа долго време беше занемарена во Словенија. Тешкотии во персоналот, застарени норми, недоволен капацитет за простор (во домовите за нега). А тука е и вирусот, а со тоа и првичен недостаток на заштитна опрема, надополнет со понекогаш контрадикторни упатства, наведува Јасна Цајнко, директор на домот за нега во Тезно “. (Жорж, Братина, Полак, Ивановиќ и Штравс, 2020 година). Таквата перспектива треба да се промени, и долгорочната грижа треба да се гледа како алтернатива на институционалната грижа.

Жртвите на вирусот во Словенија во првиот бран беа скоро исклучиво стари лица, над три четвртини од жртвите беа жители на домови за стари лица. Можеме да се согласиме за објаснувањето дека жителите во домовите за згрижување се поболни, поранливи, што пак резултира со поголема смртност. Ова е делумно точно. Сепак, има најмалку двојно повеќе потенцијални корисници на долгорочна нега надвор од институциите, многу од нив се споредливи по старост и по здравје со оние во нивните домови. Наспроти ова, дури и земајќи го предвид ,пристрасниот примерок“ (намалена видливост и набљудување или препознатливост во заедницата), стапката на смртност во заедницата требаше да биде поголема - според одредена проценка, стапката на смртност надвор од заедницата треба да биде барем еднаква ако не и поголема. Да се биде старо лице е предуслов, а не причина за фаталниот исход. Податоците покажуваат дека институционализацијата е неопходна клаузула, која во комбинација со првата доведува до инфекција и смрт.

Со подетално разгледување, јасно е дека алтернативите на институционалната грижа подразбираат помал ризик. Луѓето на кои им е потребна долгорочна нега и кои не се во институции добиваат домашна или семејна грижа, услуги за домашна нега или лична помош. ${ }^{18}$ Во сите овие форми на грижа во заедницата е можно, во таква вонредна ситуација, да се намалат контактите на посакуван минимум, споредливо со самоизолацијата кај помладите групи

18 Покрај овие форми на згрижување во заедницата, постојат можности за мали групни домови, заштитено домување и цела низа инаку помалку утврдени форми на згрижување (сместување во друго семејство, заемна и соседска помош, самоорганизирање на грижа, лични пакети за услуги, итн.). 
на население, и, се разбира, под минимумот можен во институциите.

Во случај на лична асистенција, на пример, давател на грижа е едно исто лице, слично во случај на домашна или семејна грижа. Во вакви случаи, дури и ако за некое лице се грижат повеќе луѓе, бројот на негуватели може да се прилагоди и намали без значителни проблеми кои реално би се појавиле во институциите. Исто така, полесно е да се регулираат непотребните контакти и да се држат настрана. ${ }^{19}$ Поличен пристап, како и понезависна работа, исто така поттикнува поголема отчетност, внимание и внимателност на корисникот, кој исто така има поголема моќ да дејствува за неговиот или нејзиниот интерес и корист. На кратко, самоизолацијата е многу подостижен идеал во заедница отколку во институција.

Ова исто така беше практично демонстрирано за време на епидемијата. Групните карантини се покажаа како повеќе да го зголемуваат ризикот отколку да го намалуваат. Во некои целосни институции, голем дел од жителите - од

19 Ова беше направено, на пример, во некои услуги за домашна нега. Тие ја ограничија својата услуга на најитните ситуации и итните задачи. Намалувањето до таков степен е едноставно невозможно во институцијата, која треба да ги води нејзините основни функции (готвење, чистење и присуство). Во ситуација на домашна нега, неопходноста може да се процени и да се примени итноста - на пр. некој може да готви, но не може да оди да пазари. Плус, во ситуацијата на заклучување (lockdown) - луѓе кои работат од дома - имаше поголема помош на располагање каде што живеат луѓето. Што не можеше да се користи во институциите. психијатриски болници, од затвори беа отпуштени, ослободени. Ова не се случило во домовите за стари лица.

Домовите за згрижување, во почетната фаза на епидемии, всушност им понудија на жителите можност да се вратат дома или кај нивните роднини, ако тие би посакале така или би имале таква можност. И покрај очигледните предности во однос на безбедноста, само неколку жители се одлучија за такво решение - 41 жител на домови за стари лица и уште 210 лица од институции за лица со интелектуална попреченост (Пихлар, 2020 б). Овој износ претставува малку повеќе од еден процент од жителите на сите институции за социјална грижа, но само два проценти на милион жители на домови за стари лица. Причината за ваквиот слаб одговор беше дека условите за отпуштање беа невозможни. Лицето треба да продолжи да плаќа (од џеб) хонорар за домашна нега (само оброците беа ослободени), додатокот за грижа исто така ќе остане во институцијата. Лицето не можеше да се врати во институцијата до крајот на епидемијата и постоеше реална закана дека ќе се изгуби местото во објектот. ${ }^{20}$ Како и да е, главната алка што недостасуваше беше дека нема потреба од замена или

20 Во периодот по крајот на првиот бран (22.05.), имавме можност да прочитаме драматична приказна за ова (Лесјак Тушек, 2020 година), која ги опишува ситуацијата и проблемите со враќањето дома. Наскоро по објавувањето на сторијата, властите покажаа намера да надоместат некои од овие трошоци (Ла. Да., 2020; Пихлар, 2020а). 
услуга за преселување. Целиот систем е навистина поставен институционално, има мал капацитет надвор што би го поддржал преселувањето, ниту имало интерес или волја, или можеби нема идеи за негово воспоставување. ${ }^{21} \mathrm{Ce}-$ пак, постоеја идеи за преместување на заразените жители во болниците.

Наместо да се дискутира што да се прави со институциите, главната полемика беше околу тоа во која институција треба да се грижи (паркира) стара личност која се заразила со оваа болест (Јагер, 2020а; Прибац, 2020; Жорж, Братина, Полак, Ивановиќ и Штравс, 2020; Ковач, 2020). Сепак, се однесува на важни етички прашања, вклучително и прашањето за стареење, напуштање на помошта, донесување одлуки за животот и смртта на стари луѓе без нивно знаење, а да не зборуваме за согласност. Исто така, привлече внимание на некои карактеристики на институциите за кои разговараме овде (концентрација на луѓе, задржување

21 Немањето идеја за тоа што понатаму да се направи, исто така беше одлика на отпуштање од психијатриски институции и затвори. Сепак, оваа ад хок деинституционализација беше можна затоа што на отпуштените не им требаше многу вистинска грижа (или во случај на затвори, контрола на „потребата“"). Сепак, одреден број луѓе, особено оние навикнати да посетуваат болници, сепак претрпеа лишување и вознемиреност, бидејќи службите во заедницата за бездомници и ментално здравје беа затворени заради епидемиите. Понекогаш се случуваше спротивното од она што треба да се стори - наместо да се затворат институциите и значително да се зајакнат услугите на заедницата (особено оние што обезбедуваат домашна нега), вторите ги затворија вратите. на луѓе во институции или намерно спречување на нивно враќање дома како средство за самоизолација и сл.). Сепак, недостатоците на домовите за стари лица беа сведени на недостаток на опрема, недостаток на експертиза, недостаток на простории и персонал, итн. Во оваа, колку и да е легитимна и важна дебата, тежиштето на проблемот се пренесува од една во друга институција, од прашањето за целосната институција и институционализацијата до прашањето за тоа кој тип на институција е посоодветен или до предностите и недостатоците на една институција во споредба со друга. ${ }^{22}$

Можеби ќе беше подобро за жителите да бидат префрлени во болници, но исто така сигурно би било подобро ако домовите за згрижување беа зајакнати за време на епидемијата со специјалисти од медицинските и здравствените професии, снабдени со повеќе заштитни средства (повеќе и подобри маски, заштитни одела и сл.) и опрема за третман (кислород, респиратори). Би било уште подобро, ако сето ова беше овозможено дома или во некоја друга форма на објект за нега налик

22 На одредено ниво, станува збор и за пренесување одговорности и за обемот на работа. При предавањето на „жешкиот компир“, се појавија два вида „расизам“. Напуштање на помошта за стари лица - ,стареење“ и страв и неподготвеност да им се помогне на заразените - во желбата за пренесување на заразените во болници и спротивставување на ова од страна на болниците. Во двата случаи, властите толерираа таков расизам - како што тоа го прават во другите случаи на расизам, нетолеранција и говор на омраза. 
на дом кој овозможува самоизолација (на пр. заштитено домување во итни случаи, итн.).

Трансферот во болницата за многумина може да биде премин ,од лошо кон полошо“. Познатиот англиски епидемиолог Том Џеферсон, кој работи во Италија, забележува дека заминувањето на старо лице во болница е скоро сигурна смртна казна (Сајовиќ, 2020). Веројатно затоа што болниците се споредливо поопасни места, но исто така и затоа што една стара личност е поранлива кога се преместува. Покрај тоа, тој се залага не само за домашна нега, туку и за домашно лекување, бидејќи современата технологија го дозволува тоа.

Самоизолацијата е најефективната алатка за запирање на епидемијата, но, од перспектива на социјалната правда, е исто така луксуз. Оние што се наоѓаат на екстремна социјална маргина - од една страна жители на социјални институции или бездомници од друга - ниту едни не можат да си го дозволат тоа, бидејќи немаат свој дом за да се засолнат. Во случај на епидемии, ова беше многу пофатално прашање за жителите на домовите за стари лица.

\section{Човештвото е заштитен фактор - потреба за деинституционализација}

Може да се заклучи дека институциите за стари луѓе беа клучниот чекор на епидемијата. Во споредба со целата вознемиреност на епидемиите, таа беше прилично запоставена и зане- марена. Здравството, јавното здравство беа во првите редови - социјалната грижа се сфати како фантомски додаток на овие. Бројките раскажуваат сосема друга приказна. Подобро дејствување во оваа област можеше да спречи многу инфекции и смртни случаи. Ова важи уште повеќе за во иднина, бидејќи се неопходни системски мерки за да се спречи можноста за пренесување на инфекцијата на подобар начин.

Овие системски промени се - деинституционализација и долгорочна грижа. Ова не се еднократни мерки што може да се направат преку ноќ. Сепак, можно е да се воспостават доволно брзо некои механизми што ќе ги зајакнат надворешните услуги во заедницата, ќе овозможат повеќе транзиции кон домашното опкружување, поголема самоизолација итн. - пред сѐ, да даваат поголема моќ и контрола и можност за нечие сопствено дејствување на стари лица и други корисници на услуги.

Во однос на деинституционализацијата, исто така е неопходно да се запре реторичкото повторување, воздржувањето на потребата од градење повеќе институции - ова се повторува одново за време на епидемијата, и покрај очигледното негативно влијание и негативните последици што ги покажаа овие институции. Мора да се повтори дека ни требаат подобри услуги во заедницата и помоќна мрежа на услуги на теренот, каде што луѓето живеат - поголема домашна нега, лична помош, координирана грижа, заштитено 
сместување и повеќе придонес во неформалните форми на грижа.

Но, можно е брзо да се изменат или подобрат неколку работи, барем до одреден степен, во самите институции - да се овозможи индивидуализација, персонализирање на грижата, за да се зголеми моќта на жителите при донесување одлуки за услугите што ги добиваат. Ова е можно до одреден степен со воведување на некои клучни новини како што се лично планирање, застапување, клучни работници, зајакнување на жителите, соодветна грижа, единици на домаќинства итн. Со нив можеме да ги смениме ставовите, атмосферата, статусот и улогите на жителите во институциите - што е вредност само по себе и не е само инструмент за спречување на контаминацијата (Мали и др. 2018).

Со прегледот на достапните податоци од перспектива на целосната институција, можевме со голема сигурност да идентификуваме некои од прашањата што укажуваат на институционалната димензија на епидемијата - дека, иако вирусот корона не е, се разбира, класична институционална инфекција или болест, има некои такви карактеристики, дека старите домови беа главниот, но занемарен момент - ако не инфекциите, тогаш фаталните последици, дека ова е структурно прашање што може да се спречи со деинституционализација и семоќна долгорочна нега. Но, станува збор и за односот и пристапот. Институционалната грижа им ја одзема моќта на веќе немоќните жители, ги тран- сформира во предмети, ги прави да изгледаат помалку човечки и ги префрла грижите и неволјите на местата надвор од видното поле - што пак експлодираат во времето на короната.

Епидемијата на вирусот корона предупредува не само за климатските промени, прекумерниот консумеризам, проблемот со поделба на трудот и другите недостатоци на денешната социјална „шминка“, туку и заради она што не сакавме да го забележиме, токму во срцето на епидемијата, во стапката на смртност, се согледува злобноста и нечовечноста на институциите создадени пред околу два века за најслабите членови на општеството. Како и за другите работи што се појавија во епидемијата, постои можност за нешто ново, за значајна акција, во овој случај ова е буквално прашање на живот и смрт.

\section{Пост скриптум}

Како што е забележано, најголемиот дел од овој текст е напишан на крајот на првиот бран епидемии, во надеж дека ќе се научат некои лекции и ќе се спречат некои смртни случаи. Ова, сепак, не се случи. Во Словенија и во некои други земји институциите се уште се фокусирани на контаминација и смртност во вториот бран. Дури и во некои институции кои се наменети за деинституционализација и каде што има достапни ресурси за преселување, короната го запре процесот, што треба да се забрза за да се спречи катастрофата. На пример, дополнителниот ангажиран 
персонал беше ставен во мирување наместо да го поддржува преоптоварениот постоечки персонал, наместо брзото преселување и дисперзија на жителите и вработените (во меурчиња) жителите станаа уште позаклучени и воздржани. Достапните ресурси за стекнување нови простории во заедницата се замрзнаа од какви било бирократски причини - на многу начини короната го зајакна бирократскиот вирус.

Немаше зајакнување на службите во заедницата, ниту стимулации за домашна грижа - да се вратат во домовите или кај роднини за оние кои ја имаат оваа можност, ниту лично планирање и измислување нови решенија за оние кои немаат. Наместо тоа, енергијата се трошеше во прилично непродуктивни размислувања за црвените и сивите зони, како да се наметнат построги ограничувања и контрола.

Не само што беа пропуштени можностите да се измисли и организира нешто ново, да се трансформираат институциите, жителите се најдоа во ,затвори со висок степен на безбедност“" - не смеат да излегуваат надвор, посетите се забранети или значително намалени (некои посетители убаво се сеќаваат на затворските услови од еден час неделно посета, во посебен простор, со придружник итн.). Внатрешните услуги, како физиотерапија, терапија за работа, групи за поддршка беа значително намалени, а односот помеѓу персоналот за нега и жителите се влоши заради постојаната затвореност, стресот и без значаен контакт со надворешниот свет.

Ова имаше катастрофални ефекти врз жителите - луѓето со лесна деменција не успеаја да ги препознаат своите блиски откако ќе имаа конечно можност да ги видат, жителите со проблеми со мобилноста станаа уште понеподвижни и остатокот на движење се намали, без посетители тие престанаа ги очекуваат своите најблиски и без надворешен свет тие се повеќе се зафќаа во лавиринтот на институционалните односи, тие почнуваа да се чувствуваат уште повеќе како предмети, помалку како лица и многумина се откажуваа и развиваа она што лекарите би го нарекле депресија (што во староста е пат кон смрт). Очигледно е дека короната, покрај тоа што инфицира и убива луѓе, зема уште еден данок - индиректните лоши ефекти може да бидат катастрофални како и директните - но овие не се преброени. 


\section{Референци}

Flaker, V. (1998). Odpiranje norosti: Vzpon in padec totalnih ustanov. Ljubljana: Založba */cf. Flaker, V. (2015). Deinstitutionalisation as a machine, Dialogue in Praxis, vol. 4., no. 1-2. Available at: http://dialogueinpraxis.fsd.uni-lj.si/index.php?id=5\&a=article\&aid=45

Goffman, E. (1961). Asylums, Doubleday, New York (Pelican edition 1968).

Jager, V. (2020a). So bili starostniki že vnaprej odpisani? (Je delež starostnikov, ki so umrli $\mathrm{v}$ domovih za starejše, tako izstopajoče visok zaradi seznamov odpisanih?). Mladina, $15^{\text {th }}$ May, 2020. Accessed $25^{\text {th }}$ May 2020 at: https://www.mladina.si/198410/so-bilistarostniki-ze-vnaprej-odpisani/?fbclid=IwAR3xVmY61W1JNNqytbcMugcngZcT5 ZT_atRwhB_AiLHRRjvy4yq5CWSUIvs

Jager, V. (2020b). V domovih za starejše obstajajo seznami odpisani, ki ne smejo priti v bolnišnico. (Intervju z Dušanom Kebrom). Mladina 20, $15^{\text {th }}$ May 2020, pp. 39-42.

Kovač, V. (2020). Odločitev, da se bolne in okužene zadrži v domovih, je bila slaba in ima tragične posledice (Pri nas je umrlo 106 ljudi, od tega jih je bilo 86 oskrbovancev domov za starejše). TV Slovenija, 23 ${ }^{\text {rd }}$ May 2020, MMC RTV SLO. Accessed 24 $4^{\text {th }}$ May 2020 at: https://www.rtvslo.si/zdravje/novice/odlocitev-da-se-bolne-in-okuzene-zadrzi-vdomovih-je-bila-slaba-in-ima-tragicne-posledice/ 524860

La. Da. (2020). Sprejem novih oskrbovancev v domove za starejše možen s 25. majem? (Obeta se povračilo za svojce, ki so oskrbovance med epidemijo nastanili doma). MMC RTV $S L O, S T A, 20^{\text {th }}$ May 2020. Accessed 24 ${ }^{\text {th }}$ May 2020 at: https://www.rtvslo.si/slovenija/ sprejem-novih-oskrbovancev-v-domove-za-starejse-mozen-s-25-majem/524512

Lesjak Tušek P. (2020). Socialnozdravstveni zavodi in covid-19: Bili so doma, a plačali za oskrbo v zavodu. Večer, $22^{\text {nd }}$ May 2020. Accessed 24 ${ }^{\text {th }}$ May 2020 at: https://www. vecer.com/socialnozdravstveni-zavodi-in-covid-19-bili-so-doma-a-placali-za-oskrbov-zavodu-10173216

Mali, J. (2008). Comparison of the characteristics of homes for older people in Slovenia with Goffman's concept of the total institution. European journal of social work, vol. 11 , no 4, str. 431-443.

Mali, J., Flaker, V., Urek, M., Rafaelič, A. (2018). Inovacije v dolgotrajni oskrbi : primer domov za stare ljudi. Ljubljana: Fakulteta za socialno delo.

Meden Marolt B. (2020). Facebook [post on topic of Covid mortality in old age homes $14^{\text {th }}$ May]. Accessed 24 $4^{\text {th }}$ May at: https://www.facebook.com/photo.php?fbid=102204377 $49326559 \&$ set $=$ a.4855946369296\&type $=1 \&$ theater

Menzies, L.I. (1988), Containing Anxiety in Institutions. London: Free Association Books. Pihlar, T. (2020). Katera številka o umrlih v bolnišnicah je prava? Dnevnik, $22^{\text {nd }}$ May 2020. Accessed 24 $4^{\text {th }}$ May 2020 at: https://www.dnevnik.si/1042929990/slovenija/ katera-stevilka-o-umrlih-v-bolnisnicah-je-prava.

Pihlar, T. (2020b). Domovi starejših: nad koronavirus tudi s praznimi posteljami. Dnevnik, Zdravje, $25^{\text {th }}$ May 2020. Accessed $25^{\text {th }}$ May at: https://www.dnevnik.si/1042930302/ slovenija/domovi-starejsih-nad-koronavirus-tudi-s-praznimi-posteljami-

Pribac, I. (2020). Smo res to storili? Mladina, 21/22. 5. 2020, str. 50-51.

Sajovic, K. (2020). Na tej točki karantena ni ravno smotrna - duh je že ušel iz stekleničke: Intervju z britanskim epidemiologom Tomom Jeffersonom. $1^{\text {st }}$ April 2020, Rim - MMC 
RTV SLO. Accessed 24 $4^{\text {th }}$ May 2020 at: https://www.rtvslo.si/zdravje/novi-koronavirus/ na-tej-tocki-karantena-ni-ravno-smotrna-duh-je-ze-usel-iz-steklenicke/519071?fbclid= IwAR0SprqgBhwo3wM4sHBIbkhNHKJRSIGDwJy-4ToLipnazcTXKpfRQvvIQYM. Huber, M., Rodrigues, R., Hoffmann, F., Marin, B., Gasior, K. (2009). Fact and Figures on Long - Term Care: Europe and North America. Vienna; European Centre for Social Welfare Policy and Research.

Žorž, M., Bratina, Š., Pollak, T., Ivanovič, U., Štravs, A. (2020). Prvi val domove za starejše ujel nepripravljene, zdaj je čas za odpravo napak. Domovi za starejše: Cone neudobja. Radio Slovenija, 17 th May 2020, MMC RTV SLO, Radio Slovenija. Accessed $24^{\text {th }}$ May 2020 at: https://www.rtvslo.si/slovenija/ prvi-val-domove-za-starejse-ujel-nepripravljene-zdaj-je-cas-za-odpravo-napak/524085 